\title{
Similarity in Visual Word Recognition: The Effect of Syllabic Neighborood in French
}

S. Mathey and D. Zagar

\section{(2) OpenEdition \\ 1 Journals}

\section{Electronic version}

URL: http://journals.openedition.org/cpl/210

DOI: $10.4000 / \mathrm{cpl} .210$

ISSN: $1379-6100$

\section{Publisher}

Centre PsyCLÉ

\section{Printed version}

Date of publication: 1 August 2002

\section{Electronic reference}

S. Mathey and D. Zagar, « Similarity in Visual Word Recognition: The Effect of Syllabic Neighborood in French », Current psychology letters [Online], 2002/2, 8 | 2002, Online since 05 September 2003, connection on 08 September 2020. URL : http://journals.openedition.org/cpl/210 ; DOI : https:// doi.org/10.4000/cpl.210

\section{This text was automatically generated on 8 September 2020}

(C) All rights reserved 
Similarity in Visual Word Recognition: The Effect of Syllabic Neighborood in French

S. Mathey and D. Zagar 